\title{
Effect of Pretreatment of Sulfide Refractory Concentrate with Sodium Hypochlorite, Followed by Extraction of Gold by Pressure Cyanidation, on Gold Removal
}

\author{
Alejandro Valenzuela ${ }^{1,2 *}$, Jesús L. Valenzuela ${ }^{1}$, José R. Parga ${ }^{2}$ \\ ${ }^{1}$ Department of Chemical Engineering and Metallurgy, University of Sonora, Hermosillo, México \\ ${ }^{2}$ Department of Metallurgy and Materials Science, Institute Technological of Saltillo, Saltillo, México \\ Email: *avalens@iq.uson.mx
}

Received May 21, 2013; revised June 20, 2013; accepted July 1, 2013

Copyright (C) 2013 Alejandro Valenzuela et al. This is an open access article distributed under the Creative Commons Attribution License, which permits unrestricted use, distribution, and reproduction in any medium, provided the original work is properly cited.

\begin{abstract}
The majority of the refractory gold and silver occurs in occlusion in sulphides, then precious metal dissolution is possible by first oxidizing auriferous sulfide concentrate using sodium hypochlorite-sodium-hydroxide solution followed of pressure cyanidation of the oxidized concentrate, for the extraction of precious metals. This process was conducted and evaluated under cyanide and oxygen pressure. This versatile approach offers many advantages, including low temperatures, low pressure and less costly materials of construction than conventional pressure oxidation. In this study, the effect of oxygen pressure, concentration of sodium hypochlorite, temperature, and initial $\mathrm{pH}$, in precious metals recovery and As removal were evaluated using a $2^{4}$ factorial design. Characterization of the ores showed that pyrite and arsenopyrite were the main minerals present on the concentrate. The best results for gold extraction were obtained with oxygen pressure of $80 \mathrm{psi}, 10 \%(\mathrm{w} / \mathrm{w})$ sodium hypochlorite, temperature of $80^{\circ} \mathrm{C}$, at $\mathrm{pH}=13$, and a constant stirring speed of $600 \mathrm{rpm}$. These conditions allowed an approximated $60 \%$ of gold and $90 \%$ of silver extractions in $1 \mathrm{hr}$.
\end{abstract}

Keywords: Refractory Gold Concentrate; Hypochlorite Oxidation Pretreatment; Pressure Cyanidation

\section{Introduction}

\subsection{Background}

Many of the gold deposits contain finely disseminated gold in iron sulfide minerals such as pyrite and arsenopyrite. Such deposits are called refractory gold ores due to the encapsulation of fine particles of gold in the ore host. A clear boundary between refractory and non-refractory ore in terms of gold recovery is not well defined, but several authors have pointed out that less than $60 \%$ gold recovery by direct cyanide leaching, after fine grinding of mineral indicates a refractory mineral [1]. The refractory ore must be destroyed or attacked by chemical means with the use of oxidative processes, such as oxidation by roasting [2], pressure oxidation [3], bio-oxidation [4], and ultrafine grinding [5]. Then, a suitable pretreatment process is often required to overcome the refractoriness and render the gold and silver accessible to the lixiviante action of cyanide and oxygen [1].

Oxidative leaching of metal sulphide minerals is

"Corresponding author. commonly considered as an electrochemical reaction between sulfur and oxygen ion. The sulfide sulfur is oxidized, either in elemental sulfur, sulfite, or sulfate ions. Oxygen undergoes a reduction reaction with formation of water. Studies show two competing reactions, the reaction of anodic oxidation of pyrite, one of them yielding sulfate and sulfuric acid 1) and the other produces sulfate and elemental sulfur 2). Oxygen can also directly oxidize the pyrite producing $\mathrm{Fe}^{3+} 3$ ) and thiosulfate decomposition followed by oxidation of thiosulfate and sulfite ions to sulfate [6].

$$
\begin{gathered}
\mathrm{FeS}_{2}+7 / 2 \mathrm{O}_{2}+\mathrm{H}_{2} \mathrm{O} \rightarrow \mathrm{FeSO}_{4}+\mathrm{H}_{2} \mathrm{SO}_{4} \\
\mathrm{FeS}_{2}+2 \mathrm{O}_{2} \rightarrow \mathrm{FeSO}_{4}+\mathrm{S}^{0} \\
4 \mathrm{FeS}_{2}+7 \mathrm{O}_{2}+4 \mathrm{H}^{+} \rightarrow 4 \mathrm{Fe}^{3+}+4 \mathrm{~S}_{2} \mathrm{O}_{3}^{2-}+2 \mathrm{H}_{2} \mathrm{O}
\end{gathered}
$$

The proposed reactions of arsenopyrite are quite similar (Equations (4) and (5)), [7].

$$
\begin{aligned}
& 4 \mathrm{FeAsS}+13 \mathrm{O}_{2}+6 \mathrm{H}_{2} \mathrm{O} \rightarrow \\
& 4 \mathrm{H}_{3} \mathrm{AsO}_{4}+4 \mathrm{FeSO}_{4}
\end{aligned}
$$




$$
\begin{aligned}
& 4 \mathrm{FeAsS}+7 \mathrm{O}_{2}+2 \mathrm{H}_{2} \mathrm{O}+4 \mathrm{H}_{2} \mathrm{SO}_{4} \rightarrow \\
& 4 \mathrm{H}_{3} \mathrm{AsO}_{4}+4 \mathrm{FeSO}_{4}+4 \mathrm{~S}^{0}
\end{aligned}
$$

Pressure oxidation typically operates at moderate temperature and pressure, temperatures of $60^{\circ} \mathrm{C}$ to $80^{\circ} \mathrm{C}$ and an oxygen pressure of 60 to $80 \mathrm{psi}$. Under these conditions, the sulfide sulfur is oxidized to sulfate.

\subsection{Alkaline Oxidation}

Arsenopyrite has an economic importance, when there is more of it than gold in the ore. Oxidation of arsenopyrite is of practical and theoretical importance in processing gold ores and concentrates. However, the chemistry of arsenopyrite in relation to its dissolution, flotation, and electrochemistry has received little attention [6]. Therefore, in alkaline oxidizing conditions, arsenopyrite can be oxidized to ferrous hydroxide, arsenate $\left(\mathrm{HAsO}_{4}^{2-}\right.$ or $\mathrm{AsO}_{4}^{3-}$ depending on $\mathrm{pH}$ ), and to sulfate with iron hydroxides and arsenites as intermediates. The overall reaction for the alkaline oxidation of arsenopyrite might be described by the following equation:

$$
\begin{aligned}
& 2 \mathrm{FeAsS}+10 \mathrm{OH}^{-}+7 \mathrm{O}_{2} \rightarrow \\
& \mathrm{Fe}_{2} \mathrm{O}_{3}+2 \mathrm{SO}_{4}{ }^{2-}+2 \mathrm{AsO}_{4}^{3-}+5 \mathrm{H}_{2} \mathrm{O}
\end{aligned}
$$

Studies by Poling and Beattie [6] indicate that the oxidation of arsenopyrite, forms iron hydroxide films on the surface of the mineral at $\mathrm{pH}$ values above 7 . Bhakta et al. [6] found that the lower oxidation potential of arsenopyrite occurs in caustic solutions. Research the electrochemical behavior of arsenopyrite in alkaline media using cyclic voltammetric at $\mathrm{pH} 8-12$. Their work suggests that the anodic oxidation of the arsenopyrite is a two-phase dissolution mechanism. The first step is:

$$
\begin{aligned}
& \mathrm{FeAsS}+6 \mathrm{H}_{2} \mathrm{O} \rightarrow \\
& \mathrm{Fe}(\mathrm{OH})_{3}+\mathrm{H}_{2} \mathrm{AsO}_{3}{ }^{-}+\mathrm{S}^{0}+7 \mathrm{H}^{+}+6 \mathrm{e}^{-}
\end{aligned}
$$

with the formation of: a surface layer of $\mathrm{FeOOH}$, elemental sulfur, and arsenite $\left(\mathrm{H}_{2} \mathrm{AsO}_{3}\right)$. The second step involves the oxidation of arsenite $\left(\mathrm{H}_{2} \mathrm{AsO}_{3}\right)$ to arsenate $\left(\mathrm{HAsO}_{4}^{2-}\right.$ ) and sulfate sulfur according to the following reactions:

$$
\begin{gathered}
\mathrm{H}_{2} \mathrm{AsO}_{3}^{-}+\mathrm{H}_{2} \mathrm{O} \rightarrow \mathrm{HAsO}_{4}^{2-}+3 \mathrm{H}^{+}+2 \mathrm{e}^{-} \\
\mathrm{S}^{0}+4 \mathrm{H}_{2} \mathrm{O} \rightarrow \mathrm{SO}_{4}^{2-}+8 \mathrm{H}^{+}+6 \mathrm{e}^{-}
\end{gathered}
$$

At higher potentials, the oxidation products of arsenopyrite; are elemental sulfur and arsenate in accordance with the following overall equation:

$$
\mathrm{FeAsS}+7 \mathrm{H}_{2} \mathrm{O} \rightarrow \mathrm{Fe}(\mathrm{OH})_{3}+\mathrm{HAsO}_{4}^{2-}+\mathrm{S}^{0}+10 \mathrm{H}^{+}+8 \mathrm{e}^{-}
$$

In the oxidation, ferric hydroxide and elemental sulfur precipitates on the surface of the particle. These com- pounds significantly reduce gold extraction during the subsequent recovery step by cyanidation of the neutralized residue. There are few studies on the chemical leaching of arsenopyrite in alkaline oxidizing media. The oxidation reactions, which take place in $\mathrm{NaOH}$ aqueous solutions, are suggested as follows:

$$
\begin{aligned}
& 3 \mathrm{FeAsS}+9 \mathrm{NaOH}+4 \mathrm{O}_{2} \rightarrow \\
& 2 \mathrm{Na}_{3} \mathrm{AsO}_{4}+\mathrm{Na}_{3} \mathrm{AsS}_{3}+3 \mathrm{Fe}(\mathrm{OH})_{3}
\end{aligned}
$$

Subsequent oxidation of $\mathrm{AsS}_{3}^{-3}$ produces $\mathrm{SO}_{4}^{-2}$ and $\mathrm{AsO}_{4}^{-3}$.

Arsenopyrite oxidation rate depends on the concentrations of oxygen and alkali, temperature, surface or size of mineral particles, the pulp density of the mixture, stirring and reaction time.

Based on studies, on the published data and on experience, it can be assumed that the oxidation of pyrite and arsenopyrite in sodium hypochlorite solutions, are made in strongly alkaline conditions and high potential conditions, close to $1.2 \mathrm{~V}$, a region where hypochlorite ion is stable, according to Eh-pH diagram, Figure 1(b) $\left(\mathrm{H}_{2} \mathrm{O}-\mathrm{O}_{2}-\mathrm{Cl}_{2}\right)$ and in Figure 1(a), (Fe-As-S-O- $\left.\mathrm{H}_{2} \mathrm{O}\right)$ stable species are observed for iron under these conditions; therefore the oxidation of pyrite and arsenopyrite, are given according to the following reactions:

Arsenopyrite

$$
\begin{gathered}
\mathrm{FeAsS}+5 \mathrm{NaClO}+\mathrm{O}_{2}+2 \mathrm{NaOH} \rightarrow \\
\mathrm{FeAsO}_{4}+\mathrm{Na}_{2} \mathrm{SO}_{4}+5 \mathrm{NaCl}+\mathrm{H}_{2} \mathrm{O} \\
\mathrm{FeAsS}+4 \mathrm{NaClO}+1.5 \mathrm{O}_{2}+5 \mathrm{NaOH} \rightarrow \\
\mathrm{Na}_{3} \mathrm{AsO}_{4}+\mathrm{Na}_{2} \mathrm{SO}_{4}+\mathrm{Fe}(\mathrm{OH})_{3}+4 \mathrm{NaCl}+\mathrm{H}_{2} \mathrm{O} \\
\text { Pyrite } \\
\mathrm{FeS}+5.5 \mathrm{NaClO}_{2} \mathrm{O}_{2}+4 \mathrm{NaOH} \rightarrow \\
\mathrm{Fe}(\mathrm{OH})_{3}+2 \mathrm{Na}_{2} \mathrm{SO}_{4}+5.5 \mathrm{NaCl}+0.5 \mathrm{H}_{2} \mathrm{O}
\end{gathered}
$$

\subsubsection{Hypochlorite as Oxidizing Medium}

Although the conventional direct cyanidation has been used commercially for extraction of precious metals, several studies are being conducted on alternative processes, as there are minerals that do not respond satisfactorily, classified as refractory ores, that require long leach without reaching satisfactory results. To achieve the extraction of precious metals several pretreatments are required.

For extraction of gold from refractory ores or concentrate, in which gold is surrounded or covered by iron sulfide minerals, mainly arsenopyrite and pyrite, mineral oxidative pretreatment is essential to oxidize sulfides and to expose gold to the leaching solution. Pyrometallurgical oxidation by roasting is under environmental restrictions [1]. Therefore, hydrometallurgical methods are preferred as they have better potential. These methods in- 


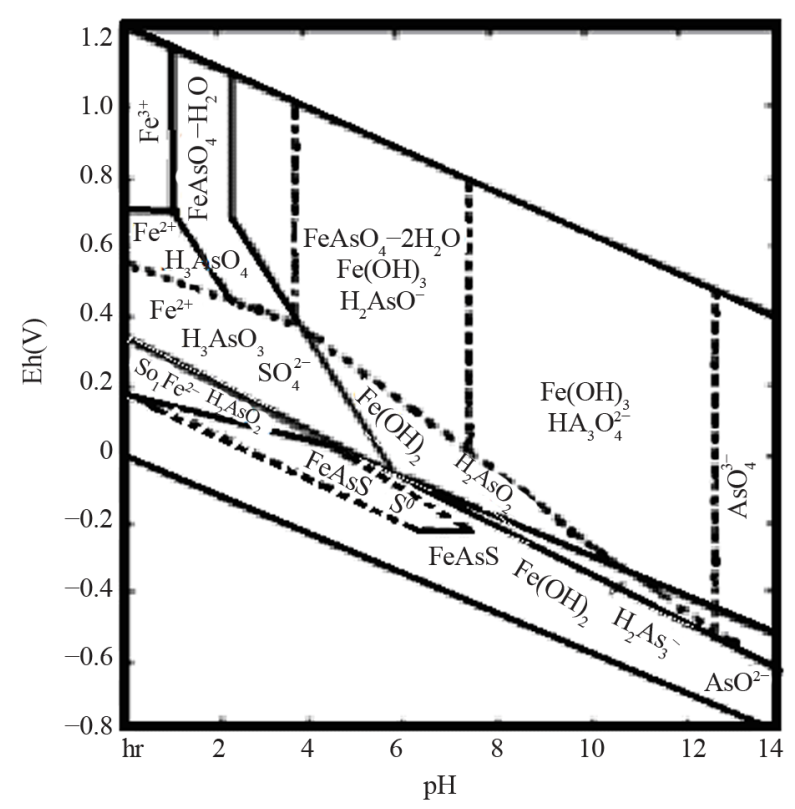

(a)

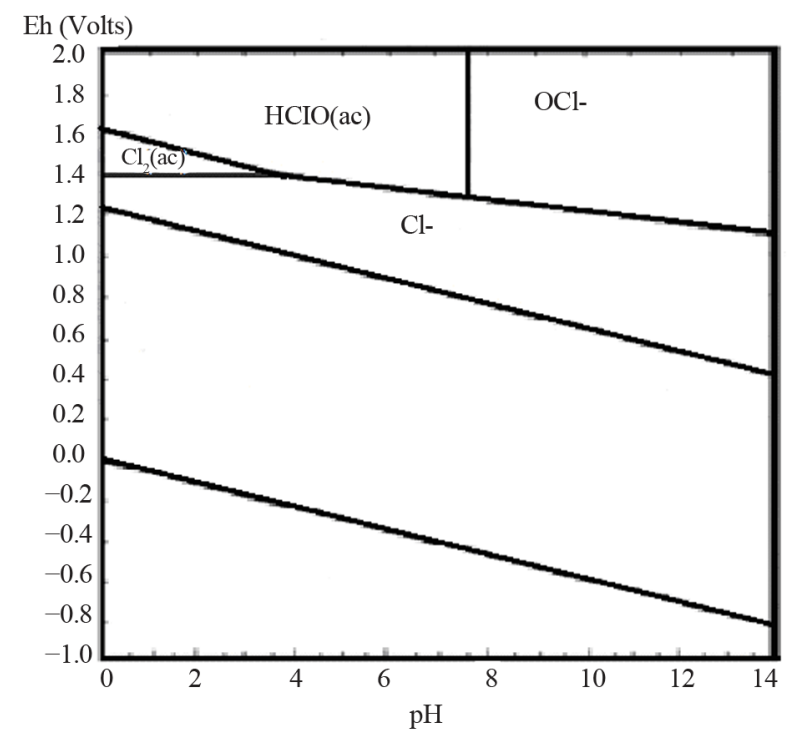

(b)

Figure 1. (a) Eh-pH Diagram of Fe-As-S-O- $\mathrm{H}_{2} \mathrm{O}$ system [1]; (b) Eh-pH Diagram for $\mathrm{H}_{2} \mathrm{O}-\mathrm{O}_{2}-\mathrm{Cl}_{2}$ system [6].

clude pressure oxidation $[7,8]$, biological oxidation [911 ], and nitric acid oxidation [12].

Chlorine gas in aqueous solutions, depending on the $\mathrm{pH}$, can form three oxidizing species: aqueous chlorine $\left(\mathrm{Cl}_{2(\mathrm{aq})}\right)$, hypochlorous acid $(\mathrm{HOCl})$ and hypochlorite ions $\left(\mathrm{OCl}^{-}\right)$. Concentration of these species is determined by the following equations and equilibrium constants:

$$
\begin{aligned}
& \mathrm{OCl}^{-}+\mathrm{H}^{+} \rightarrow \mathrm{HClO} \mathrm{K}=10^{7.5} \\
& \mathrm{Cl}_{2(\mathrm{aq})}+\mathrm{H}_{2} \mathrm{O} \rightarrow \mathrm{HClO}+\mathrm{H}^{+}+\mathrm{Cl}^{-} \\
& \mathrm{K}=4.1 \times 10^{-4}
\end{aligned}
$$

Those three species can be generated by adding sodium hypochlorite $(\mathrm{NaOCl})$ or calcium hypochlorite $\left(\mathrm{Ca}(\mathrm{OCl})_{2}\right)$ to an aqueous solution. Calcium hypochlorite is more stable than sodium hypochlorite and contains a higher concentration of chlorine.

These salts ionize in water, under acidic conditions $(\mathrm{pH}<7.5)$. Hypochlorite ion becomes hypochlorous acid in very acidic conditions $(\mathrm{pH}<3.5)$, and in the presence of chloride ions, aqueous chlorine is formed. Therefore, $\mathrm{pH}$ should be maintained in the range of stability of $\mathrm{OCl}^{-}$, Figure 1(b). In hypochlorite solutions, in the $\mathrm{pH}$ range in which hypochlorite ion $\left(\mathrm{OCl}^{-}\right)$prevails, all sulfides commonly associated with gold readily oxidize. Pyrite is the most stable of metal sulfides, this means that if in aqueous solution, pyrite is oxidized; other sulfides will surely be oxidized. Pourbaix diagram of Fe-S, shows that pyrite decomposes into iron hydroxide and sulfate in the range of the hypochlorite ion. Oxidation of sulfides in hypochlorite solutions in alkaline medium has an advantage, which is sulphate formation instead of elemental sulfur that can passivate the surface of the mineral particles [13].

\section{Materials and Methods}

\subsection{Materials}

The ore used was provided by Williams Mining, it was a complex of sulphides (pyrite and arsenopyrite) from a flotation bulk concentrate.

\subsection{Reagents}

Among others, the following regents were used; sodium hypochlorite $(\mathrm{NaOCl})$, sodium hydroxide $(\mathrm{NaOH})$ as $\mathrm{pH}$ adjuster, oxygen as the oxidant in the pressure reactor and sodium cyanide $(\mathrm{NaCN})$.

\subsection{Equipment}

The following equipment was used: a one liter stainless steel reactor (Parr, series 4520) to carry out Alkaline oxidation pretreatment and pressurized cyanidation; a Perkin Elmer Analyst 400 atomic absorption spectrometer to determine concentration of gold, silver and arsenic, for the fire analysis, muffles, hot plates, and a variety of glassware were used, an X-ray Diffraction Microscope (XRD) and a JEOL 5410LV, Tokyo, Japan Scanning Electron Microscope (SEM) for characterization of samples.

\section{Experimental Methodology}

The first step was characterization of the ore and oxidized solid product.

Next, a diagnostic test of stirred conventional cyanidation was performed, under the following conditions: 100 $\mathrm{g}$ of sample, $0.10 \% \mathrm{NaCN}$, pulp to $15 \%(\mathrm{w} / \mathrm{w}), \mathrm{pH}=11$ 
(adjusted with $\mathrm{NaOH}$ ) and 72 hours treatment, and with mechanical stirring at $750 \mathrm{rpm}$, resulting in a $6 \%$ gold and $30 \%$ silver recovery.

In order to evaluate statistically the extraction of gold, a $2^{4}$ factorial design was used. Pretreatments were run randomly and according to the conditions indicated in Table 1. The factors and levels considerated were: A, concentration of sodium hypochlorite (high $10 \%$ and low $5 \% \mathrm{w} / \mathrm{w}$ ); B, oxygen pressure (high 80, low 60 psi); C, temperature (high 80 , low $60^{\circ} \mathrm{C}$ ) and $\mathrm{D}, \mathrm{pH}$ (high 13 and low 12).

For the pressurized oxidant alkaline cyanidation, all tests were performed at the following conditions: $10 \mathrm{~g}$ of $\mathrm{NaCN}, 60^{\circ} \mathrm{C}, 60$ psi oxygen pressure, $\mathrm{pH} 11,15 \%$ (w/w) slurry and a stirring speed of $600 \mathrm{rpm}$. Before cyanidation, the oxidized ore was washed until the complete elimination of oxidizing reagents.

\section{Results}

\subsection{Characterization of the Ore and Oxidized Solid Product}

Table 2 shows the content of precious metals and arsenic of the concentrate, and Figure 2 shows the X-ray diffraction analysis, in which mineralogical species has been properly identified.

Table 1. Experimental design matrix.

\begin{tabular}{llllllllll}
\hline Run & A & B & C & D & Run & A & B & C & D \\
\hline $\mathbf{1 , 1 7}$ & - & - & - & - & $\mathbf{9 , 2 5}$ & - & - & - & + \\
$\mathbf{2 , 1 8}$ & + & - & - & - & $\mathbf{1 0 , 2 6}$ & + & - & - & + \\
$\mathbf{3 , 1 9}$ & - & + & - & - & $\mathbf{1 1 , 2 7}$ & - & + & - & + \\
$\mathbf{4 , 2 0}$ & + & + & - & - & $\mathbf{1 2 , 2 8}$ & + & + & - & + \\
$\mathbf{5 , 2 1}$ & - & - & + & - & $\mathbf{1 3 , 2 9}$ & - & - & + & + \\
$\mathbf{6 , 2 2}$ & + & - & + & - & $\mathbf{1 4 , 3 0}$ & + & - & + & + \\
$\mathbf{7 , 2 3}$ & - & + & + & - & $\mathbf{1 5 , 3 1}$ & - & + & + & + \\
$\mathbf{8 , 2 4}$ & + & + & + & - & $\mathbf{1 6 , 3 2}$ & + & + & + & + \\
\hline
\end{tabular}

Table 2. Chemical analysis of the concentrate.

\begin{tabular}{cc}
\hline ELEMENT & AMOUNT \\
\hline $\mathrm{Au}$ & $21.01 \mathrm{~g} / \mathrm{t}$ \\
$\mathrm{Ag}$ & $155 \mathrm{~g} / \mathrm{t}$ \\
$\mathrm{As}$ & $11.20 \%$ \\
$\mathrm{~S}$ & $36 \%$ \\
$\mathrm{Cu}$ & $0.14 \%$ \\
$\mathrm{Fe}$ & $39.49 \%$ \\
$\mathrm{Mn}$ & $14.20 \%$ \\
$\mathrm{~Pb}$ & $0.60 \%$ \\
\hline
\end{tabular}

Figures 3 and 4 show SEM micrographs of the ore particles, respectively, before and after the oxidizing treatment with sodium hypochlorite. Showing that the ore particles have a smooth shiny surface and oxidized ore particles show that the surface has been altered, presenting less bright, small pores, and noticing deposits of iron salts, such as sulfate and hydroxide.

Figure 4 shows the oxidizing action of sodium hypochlorite using sodium hydroxide as a $\mathrm{pH}$ regulator. The final solids weight was increased due to the formation of stable compounds that precipitate as sulfate and iron hydroxide.

\subsection{Characterization of Oxidized Concentrate Products}

Figure 5 shows the X-ray Diffractogram of the concentrate product from oxidation. It was observed that sulfur is removed as well as arsenic.

\subsection{As, Au and Ag analysis of Treated Refractory Gold Concentrate}

Once the experimental design was run on the 32 refractory concentrate samples, the next step was to determine

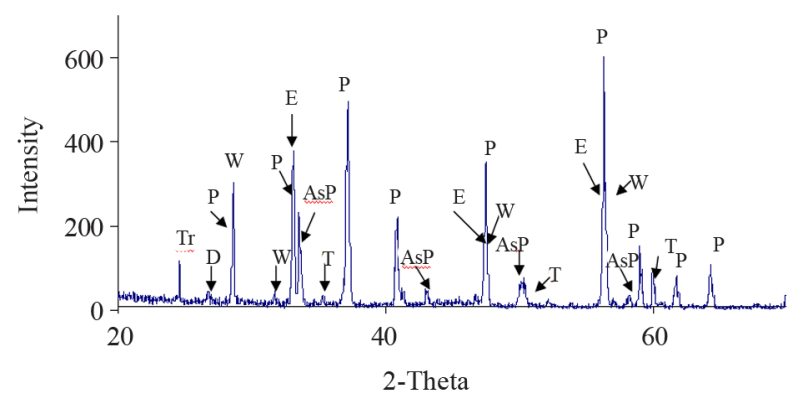

Figure 2. X-ray Diffractogram, with the mineralogical species found in the ore, AsP = Arsenopyrite (FeAsS); $W=$ Wurtzite (ZnS); E = Sphalerite (ZnS); $\mathbf{P}=$ Pyrite $\left(\mathrm{FeS}_{2}\right)$; $\mathbf{T}$ $=$ Tennantite $\left((\mathrm{Cu}, \mathrm{Fe})_{12} \mathrm{As}_{4} \mathrm{~S}_{3}\right) ; \mathrm{D}=$ Domeykite- $\beta\left(\mathrm{Cu}_{3} \mathrm{As}\right) ; \mathrm{Tr}$ $=$ Trechmannite $\left(\operatorname{AgAsS}_{2}\right)$.

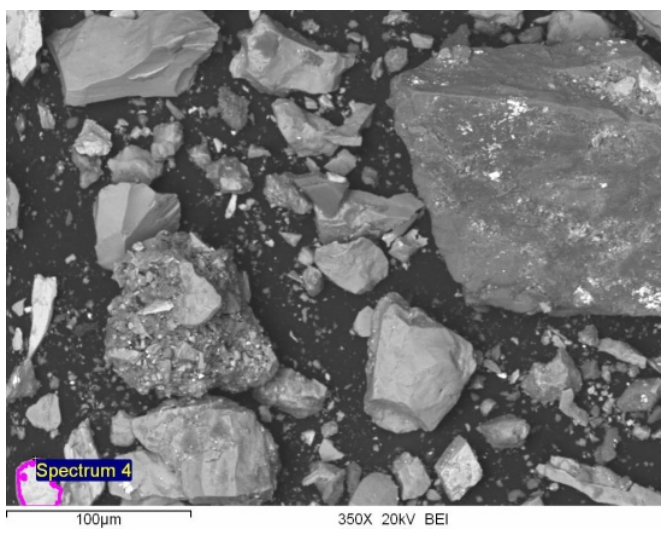

Figure 3. Micrograph of concentrate particles. 

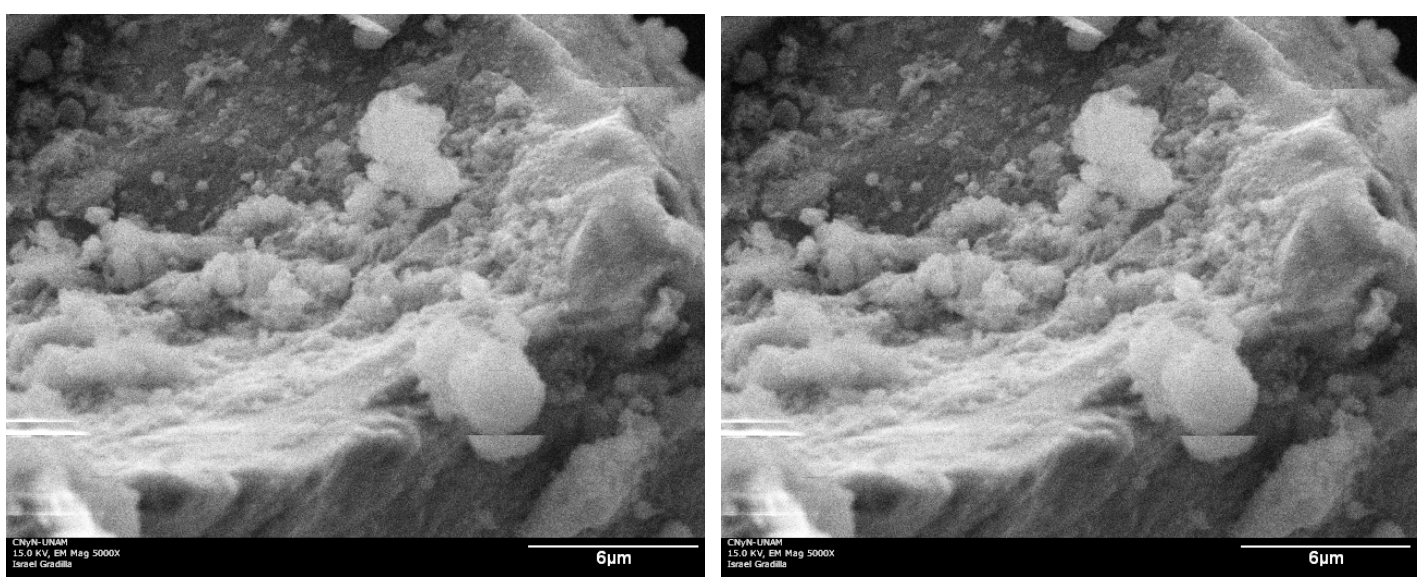

Figure 4. Micrographs of oxidized concentrate particles with NaClO.

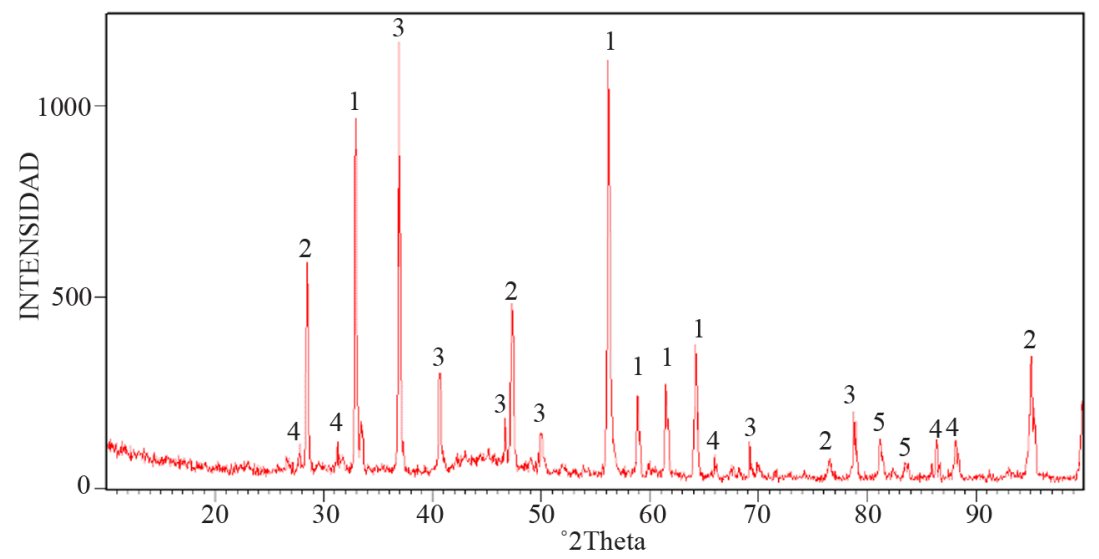

Figure 5. X-ray diffractogram, with mineralogical species found in the oxidized concentrate; 1 . pyrite $\left(\mathrm{FeS}_{2}\right)$; 2 . iron hydroxide $\left(\mathrm{Fe}(\mathrm{OH})_{3}\right)$; 3. arsenopyrite (FeAsS); 4. iron sulfate $\left(\mathrm{FeSO}_{4}\right)$; and 5. Trechmannite $\left(\mathrm{AgAsS}_{2}\right)$.

the amount of gold removed. The pretreated ore was then taken to the pressure cyanidation stage, in order to analyze $\mathrm{Au}, \mathrm{Ag}$ and $\mathrm{As}$ in the pregnant solution. The percentage of gold, silver and arsenic removal of the treated concentrate is presented in Table 3.

\subsection{Graphical Analysis of Results}

The statistical analysis was made using MINITAB. Main effects for gold removal, are shown graphically in Figure 6, (interactions are not shown). The biggest effect corresponds to the oxygen pressure, closely followed by Na$\mathrm{ClO}$ concentration, then temperature, and last $\mathrm{pH}$.

\subsection{Formulation of the Mathematical Model}

The information provided for the experimental design and analysis, allows to determine a mathematical model that can be used for prediction. It expresses the response variable - gold removal-(Y) as a function of the factors tested.

$$
\mathrm{Y}=51.36+4.975 \mathrm{~A}+5.007 \mathrm{~B}+3.987 \mathrm{C}+3.187 \mathrm{D}
$$

Table 3. \% of gold, silver and arsenic removal in the pretreated concentrate.

\begin{tabular}{cccc}
\hline Run & As \% Removal & Au \% Extraction & Ag \% Extraction \\
\hline 1 & 13.8 & 32.5 & 83.5 \\
2 & 21.7 & 48.7 & 86.5 \\
3 & 18.7 & 46.5 & 83.7 \\
4 & 37.8 & 58.7 & 86.9 \\
5 & 20.1 & 39.2 & 87.7 \\
6 & 24.9 & 51.5 & 89.5 \\
7 & 30.1 & 58.5 & 85.9 \\
8 & 44.3 & 61.9 & 89.9 \\
9 & 30.5 & 40.8 & 88.9 \\
10 & 36.7 & 53.7 & 90.6 \\
11 & 37.5 & 52.7 & 89.5 \\
12 & 46.1 & 59.3 & 90.9 \\
13 & 36.8 & 48.5 & 87.3 \\
14 & 43.3 & 56.1 & 85.6 \\
15 & 44.8 & 59.5 & 89.7 \\
16 & 51.0 & 66.2 & 90.6 \\
\hline
\end{tabular}




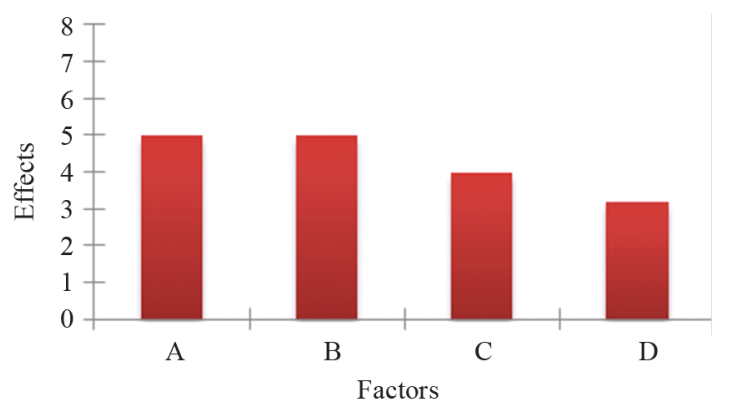

Figure 6. Graph of effect of factors on the recovery of gold, $\mathrm{A}=$ sodium hypochlorite concentration; $\mathbf{B}=$ oxygen pressure; $\mathrm{C}=$ temperature and $\mathrm{D}=\mathbf{p H}$.

This equation has an error (difference between the experimental extraction and calculated extraction) not greater than $3 \%$. Therefore, the equation can be used to predict the percentage of gold extraction at any other level of the factors analyzed, within the rank tested.

\section{Conclusions}

A preliminary alkaline pretreatment of the concentrate, using hypochlorite and pure oxygen as oxidant, increases the level of extraction of gold from $6 \%$ to $60 \%$ in one hour. Preliminary oxidant alkaline processing, increases the level of extraction of gold, due to the partial oxidation of sulfur and gold exposure to the leaching solution.

Results from the experimental factorial design indicate that the four studied factors affect significantly the gold, silver and arsenic removal. The pressure of oxygen is the most important factor, followed closely for the hypochlorite concentration, next temperature and last $\mathrm{pH}$. It is possible that the temperature effect is aliased, since it is related to the concentration of dissolved oxygen.

Oxidation of pyrite-arsenopyrite concentrate is improved by the increase of temperature and oxygen pressure, and these are related to the amount of dissolved oxygen. If these factors are high enough and their load size is small, the oxidation is complete within 30 to 60 minutes. The higher the temperature and oxygen pressure, the faster the oxidation.

The main advantage of the concentrated alkaline oxidation of pyrite-arsenopyrite gold is the smooth operation due to temperature and pressure, for they require less energy than acidic oxidation. Furthermore, the oxidation residues can lead to direct cyanidation, without requiring $\mathrm{pH}$ adjustment. The residues from cyanidation contain hydroxides and iron sulphates, which are not dangerous. Operating conditions of temperature and pressure do not require special materials for equipment.

\section{Acknowledgements}

The authors would like to thank Professors Hector Moreno and Andrew Gomes for his constructive advice dur- ing our research. This work was supported by the National Council of Science and Technology (CONACYT), University of Sonora and the Direction General of Superior Technological Education (DEGEST) from Mexico.

\section{REFERENCES}

[1] J. O. Marsden and C. I. House, "The Chemistry of Gold Extraction," 2nd Edition, S.M.E., Littleton, 2006, pp. 147-177.

[2] J. H. Coronado, M. A. Encinas, J. C. Leyva, J. L. Valenzuela, A. Valenzuela and G. T. Munive, "Tostación de un Concentrado Refractario de oro y Plata. Revista de Metalurgia,” España, Vol. 48, No. 3, 2012, pp. 165-174.

[3] L. Rusanen, J. Aromaa and O. Forsen, "Pressure Oxidation of Pyrite-Arsenopyrite Refractory Gold Concentrate," Academic Journal, Physicochemical Problems of Mineral Processing, Vol. 49, No. 1, 2013, p. 101.

[4] M. A. Márquez, J. D. Ospina and A. L. Morales, "New Insights about the Bacterial Oxidation of Arsenopyrite: A Mineralogical Scope," Minerals Engineering, Vol. 3, 2012, pp. 248-254. doi:10.1016/j.mineng.2012.06.012

[5] M. Saba, M. A. R. Fereshteh and J. Moghaddam, "Diagnostic Pre-Treatment Procedure for Simultaneous Cyanide Leaching of Gold and Silver from a Refractory Gold/Silver Ore," Minerals Engineering, Vol. 24, No. 15, 2011, pp. 1703-1709. doi:10.1016/j.mineng.2011.09.013

[6] G. H. Mehdi, F. R. Schreiberb and R. Shahram, "Simultaneous Sulfide Oxidation and Gold Leaching of a Refractory Gold Concentrate by Chloride-Hypochlorite Solution," Minerals Engineering, 2012, pp. 1-3.

[7] S. A. Awe and A. Sandstrom, "Selective Leaching of Arsenic and Antimony from a Tetrahedrite Rich Complex Sulphide Concentrate Using Alkaline Sulphide Solution," Minerals Engineering, Vol. 23, 2012, pp. 1227-1236 doi:10.1016/j.mineng.2010.08.018

[8] G. C. Jones, M. Becker, P. van H. Robert and T. L. H. Susan, "The Effect of Sulfide Concentrate Mineralogy and Texture on Reactive Oxygen Species (ROS) Generation," Applied Geochemistry, Vol. 29, 2013, pp. 199-213. doi:10.1016/j.apgeochem.2012.11.015

[9] J. Jin, S. Shi, G. Liu, Q. Zhang and W. Cong, "Arsenopyrite Bioleaching by Acidithiobacillus ferrooxidans in a Rotatingdrum Reactor," Minerals Engineering, Vol. 39, 2012, pp. 19-22. doi:10.1016/j.mineng.2012.07.018

[10] J. J. K. Gordon and E. K. Asiam, "Influence of MechanoChemical Activation on. Biooxidation of Auriferous Sulphides," Hydrometallurgy, Vol. 115-116, 2012, pp. 77-83. doi:10.1016/j.hydromet.2011.12.014

[11] A. Hol, R. D. van der Weijden, G. Van Weert, P. Kondos and J. N. Cees, "Bio-Reduction of Elemental Sulfur to Increase the Gold Recovery from Enargite," Hydrometallurgy, Vol. 115-116, 2012, pp. 93-97. doi:10.1016/j.hydromet.2012.01.003

[12] G. R. Zárate, G. T. Lapidus and R. D. Morales, “Aqueous Oxidation of Galena and Pyrite with Nitric Acid at Moderate Temperatures," Hydrometallurgy, Vol. 115-116, 2012, pp. 57-63. doi:10.1016/j.hydromet.2011.12.010 
[13] A. Basua and M. E. Schreiber, "Arsenic Release from Arsenopyrite Weathering: Insights from Sequential Ex- traction and Microscopic Studies," Journal of Hazardous Materials, Vol. 244, 2013. 